\title{
TOTOBUANG
}

$\begin{array}{lll}\text { Volume } 9 & \text { Nomor 2, Desember 2021 Halaman 197-209 }\end{array}$

\section{ANALISIS GEJALA BAHASA PADA SURAT DINAS DI KANTOR DESA PENGKOL NGUTER SUKOHARJO \\ (Analysis of Language Symptoms in Service Letters in The Village Office Of Pengkol Nguter Sukoharjo)}

\author{
Desy Anggraini a \& Yakub Nasucha ${ }^{b}$ \\ a \& b Universitas Muhammdiyah Surakarta \\ Jalan A Yani Tromol 1 Pabelan Kartasura, Surakarta, Indonesia \\ Pos-el: a310170199@student.ums.ac.id
}

Diterima: 7 Mei 2021; Direvisi: 25 Oktober 2021; Disetujui: 9 November 2021

doi: https://doi.org/10.26499/ttbng.v9i1.305

\begin{abstract}
Official letters are one of the written languages used in government agencies or organizations. Official letters sometimes do not pay attention to the correct grammatical rules. This study aims to analyze the language phenomena in official letters of the Pengkol Village Office, Nguter, Sukoharjo. This research is qualitative research using descriptive method. The data used in this study are language phenomena contained in the official lettesr of the Pengkol Village Office. The source of data in this research is an official letter made by employees of the Pengkol Village Office. The data collection technique used is the literature review, listening, and notetaking. The data analysis technique used is qualitative technique. The results of this study indicate that the language phenomena found in official letters of the Pengkol Village Head Office are interference, hypercorrection, pleonasm, and contamination. Out of the four forms of those phenomena, the most frequesnt is hypercorrection, while the least is interference.
\end{abstract}

Keywords: language symptoms, official letter, village head office

\section{Abstrak}

Surat dinas merupakan salah satu bahasa tulis yang digunakan dalam instansi pemerintah atau organisasi. Dalam surat dinas terkdang tidak memperhatikan penulisan yang sesuai dengan kaidah penggunaan bahasa yang benar. Penelitian ini bertujuan untuk menganalisis gejala bahasa yang ada dalam penulisan surat dinas di Kantor Desa Pengkol, Nguter, Sukoharjo. Penelitian ini termasuk jenis penelitian kualitatif dengan menggunakan metode deskriptif. Data yang digunakan dalam penelitian ini yaitu gejala bahasa yang terdapat dalam surat dinas Kantor Desa Pengkol. Adapun sumber data dalam penenlitian ini adalah surat dinas yang dibuat oleh pegawai Kantor Desa Pengkol. Teknik pengumpulan data yang digunakan yaitu teknik pustaka, simak, dan catat. Adapun teknik analisis data yang digunakan yaitu teknik kualitatif. Hasil penelitian ini menunjukkan bahwa gejala bahasa yang ditemukan dalam penulisan surat dinas Kantor Kepala Desa Pengkol, yaitu gejala interferensi, gejala hiperkorek, pleonasme, dan kontaminasi. Dari keempat bentuk gejala tersebut, gejala bahasa yang sering mucul adalah bentuk gejala bahasa hiperkorek, sedangkan yang paling sedikit yaitu bentuk gejala bahasa interferensi. Kata-kata kunci: Gejala bahasa, surat dinas, kantor kepala desa

\section{PENDAHULUAN}

Manusia memerlukan bahasa dalam kehidupan sehari-harinya. Tanpa adanya bahasa seseorang tidak dapat mengungkapkan gagasan dalam menyampaikan isi hatinya kepada orang lain sehingga menyebabkan keterkaitan hubungan antara bahasa dan manusia.
Bahasa muncul karena adanya sebuah interaksi-interaksi sosial yang terjadi antara satu individu dengan individu lainnya. Dengan adanya bahasa inilah seseorang dapat berkomunikasi secara etis, estetis, dan logis. Dalam kehidupan sehari-hari selalu memerlukan bahasa sebagai alat komunikasi. Seperti dijelaskan Waljinah, dkk., (2019, hlm. 118) bahwa bahasa merupakan sarana 
komunikasi yang sangat penting dalam kehidupan manusia. Pendapat tersebut diperkuat pendapat Anggara, dkk., (2020, hlm. 342) bahwa bahasa merupakan alat komunikasi yang penting karena dengan adanya bahasa manusia dapat menerima dan menyampaikan harapan, pesan dan sebagainya. Tidak ada bahasa tanpa masyarakat dan tidak ada pula masyarakat tanpa bahasa. Alat untuk berkomunikasi dan berinteraksi sosial adalah bahasa dan prosesnya disebut dengan kegiatan berbahasa (Nasucha, 2019 hlm. 148). Bahasa merupakan ungkapan secara tulis maupun lisan. Bahasa secara tulis adalah bahasa yang diungkapkan melalui tulisan-tulisan, sedangkan bahasa lisan diungkapkan secara langsung yang menyebabkan bunyi.

Surat salah satu contoh ungkapan bahasa secara tulis. Surat merupakan salah satu produk komunikasi yang sangat penting. Ali dan Tanzili (2006, hlm.1) menjelaskan surat merupakan sehelai kertas maupun lebih yang digunakan sebagai alat komunikasi untuk menyampaikan pernyataan maupun informasi secara tertulis dari suatu pihak ke pihak yang lain. Dengan demikian surat berisi mengenai informasi ataupun pesan yang diharapkan pesan tersebut dapat tersampaikan kepada penerimanya.

Surat terdiri dari dua jenis, yaitu surat dinas dan surat pribadi. Cara penulisan kedua surat itu berbeda. Surat pribadi ditulis dengan menggunakan bahasa sehari-hari tanpa memperhatikan penggunaan bahasa baku. Namun penulisan surat dinas harus menggunakan pedoman umum ejaan bahasa Indonesia. Di kalangan masyarakat awam, dalam pembuatan surat dinas tidak menggunakan kaidah-kaidah kebahasaan yang sesuai dengan PUEBI (Pedoman Umum Ejaan Bahasa Indonesia) dan struktur penulisan yang tepat. Kebiasaan tersebut menyebabkan timbulnya gejala bahasa. Gejala bahasa adalah peristiwa yang menimbulkan terjadinya penyimpangan aturan-aturan bahasa yang digunakan.
Masyarakat menganggap apa yang mereka tuturkan maupun tulis itu benar, tetapi apa yang mereka anggap benar belum tentu benar. Misalnya, seseorang sering menggunakan kata "Sholat" padahal kata yang benar dan baku sesuai kaidah PEUBI itu adalah "salat". Hal tersebut terjadi seakan-akan kata yang benar itu "Sholat".

Penelitian sejenis telah dilakukan beberapa peneliti antara lain Henilia (2021), Hesti, dkk., (2021), dan Dewi \& Nuraeni (2019). Kedua penelitian ini sama-sama meneliti surat dinas, sedangkan perbedaanya terletak pada sumber datanya. Penelitian gejala bahasa dalam surat dinas belum banyak diteliti oleh peneliti bahasa di wilayah ini. Penelitian tentang surat dinas yang dilakukan selama ini hanya berfokus pada ejaannya saja belum sampai kepada pengaruh kebiasaan masyarakatnya. Biasanya, kebiasaan penggunaan bahasa sehari-hari seringkali terbawa pada saat melaksanakan tugas atau bekerja secara resmi di kanotr pemerintahan. Hal ini juga terjadi pada masyarakat Desa Pengkol, kebiasaan pemakaian bahasa sehari-hari pada warganya itu terbawa saat pegawai kantor desa menulis surat dinas. Kekeliruan penggunaan bahasa tersebt seringkali menimbulkan gejala bahasa. oleh karena itu, dengan melihat adanya kesalahan kebahasaan sehingga menimbulkan gejala bahasa pada surat dinas di kantor Desa Pengkol, Nguter, Sukoharjo tersebut membuat peneliti tertarik untuk menelitinya. Penelitian ini diharapkan mampu meningkatkan kompetensi dan kualitas pegawai tentang penulisan surat dinas dengan tidak menimbulkan adanya gejala bahasa.

\section{LANDASAN TEORI}

Gejala Bahasa

Badudu dalam (Henilia 2021 hlm. 19) menjelaskan bahwa gejala bahasa adalah peristiwa yang menyangkut bentukanbentukan kalimat atau kata dengan segala 
macam prosesnya yang menyimpang dari aturan-aturan yang sudah ditentukan. Muslich (dalam Pratiwi dkk, 2013 hlm. 3) menyatakan bahwa penyebab perubahan bentuk kata adalah adanya perubahan beberapa kata asli karena pertumbuhan dalam bahasa itu sendiri atau karena memang adanya perubahan bentuk dari katakata pinjaman. Beberapa macam gejala bahasa terkait perubahan bahasa, di antaranya adalah, interferensi, hiperkorek, pleonasme, dan kontaminasi.

a. Interferensi

Interferensi adalah masuknya elemen bahasa lain ke bahasa tertentu secara paksa karena terjadinya kontak antarbahasa menurut Weinreich (dalam Ngalim, 2015 hlm. 69). Kridalaksana (dalam Sukoyo, 2011 hlm. 95) menjelaskan bahwa interferensi merupakan penyimpangan dari kaidahkaidah suatu bahasa sebagai akibat penguasan dua bahasa. Interferensi dari sisi bilingualism berupa penggunaan bahasa lain oleh bahasawan yang bilingual secara individual dalam suatu bahasa, ciri-ciri bahasa lain masih kelihatan berlainan dari integrasi (Kridalaksana, 1993 hlm. 84). Interferensi berbeda-beda sesuai dengan medium, ragam, gaya, dan konteks yang dipergunakan oleh orang yang bilingual itu. Interferensi berdasarkan konsep pengajarannya adalah kesalahan bahasa berupa unsur bahasa sendiri yang dibawa dialek lain yang dipelajari." Konsep tersebut menerangkan bahwa interferensi merupakan salah satu peristiwa masuknya unsur bahasa asing atau bahasa daerah ke dalam bahasa yang sedang digunakan.

(1) Berhubung kepala sekolah belum rawuh, maka acara akan ditunda lima menit.

(2) Ruko itu ada free wifi.

Contoh di atas terdapat gejala interferensi. Contoh pertama terdapat kata rawuh, kata tersebut berasal dari bahasa Jawa. Contoh kedua terdapat kata free wifi, kata tersebut berasal dari bahasa asing yaitu bahasa Inggris.

b. Hiperkorek

Hiperkorek merupakan pembetulan suatu kata yang berlebihan sehingga mengakibatkan bentuk yang sudah betul menjadi salah (Saryono dan Soedjito, 2020 hlm. 185). Muslich (2013, hlm 104) menjelaskan bahwa gejala hiperkorek adalah suatu proses pembetulan kata yang sudah betul sehingga kata tersebut menjadi salah. Badudu menerangkan terdapat lima jenis gejala hiperkorek, yaitu 1) fonem /s/ menjadi /sy/ seperti insaf menjadi insyaf, saraf menjadi syaraf, dan sah menjadi syah; 2) fonem $/ \mathrm{h} /$ menjadi $/ \mathrm{kh} / \mathrm{seperti}$ hikmah menjadi khikmah dan ahli menjadi akhli; 3) fonem /p/ menjadi /f/ seperti paham menjadi faham dan pigura menjadi figura; 4) fonem /j/ menjadi / $\mathrm{z} /$ seperti ijazah menjadi izazah; dan 5) vokal /o,e/ menjadi diftong /au/ seperti teladan menjadi tauladan.

\section{c. Pleonasme}

Pleonasme merupakan kesalahan berbahasa yang disebabkan oleh penggunaan kata yang berlebihan dalam pemakaian maupun penggunaan kata yang tidak diperlukan (Markhamah dan Atiqa, 2014 hlm 133). Penjelasan tersebut selaras dengan pendapat Gita (2018, hlm. 157) pleonasme adalah penggunaan kata-kata yang berlebihan yang tidak dibutuhkan dan tidak berpengaruh terhadap kalimat serta tidak mengubah makna kalimat. Kata mubazir dalam ilmu bahasa sering disebut pleonasme. Pleonasme merupakan kesalahan berbahasa yang disebabkan oleh penggunaan kata yang berlebihan dalam pemakaian maupun penggunaan kata yang tidak diperlukan (Markhamah dan Atiqa, 2014 hlm. 133). Jadi, pleonasme (kemubadziran) adalah pemakaian kata-kata yang berlebihan sehingga kalimat menjadi tidak efektif. Badudu (dalam Adib, 2019 hlm. 43) menjelaskan terdapat tiga macam bentuk 
pleonasme. Pertama, dua kata atau lebih yang mempunyai makna sama dipakai dalam suatu ungkapan. Kedua, pada suatu ungkapan yang terdiri lebih dari satu kata, kata selanjutnya seharusnya tidak diperlukan, karena maknanya sudah terkandung pada kata sebelumnya atau kata pertama. Ketiga, bentuk kata yang dipakai mengandung makna yang sama dengan kata lain yang dipakai bersama-sama pada sebuah ungkapan.

(1) Saya ucapkan terima kasih sebanyak-banyaknya atas kehadirannya.

(2) Para ibu-ibu mohon untuk datang sesuai waktu yang sudah di sepakati.

Contoh di atas terdapat gejala pleonasme. Contoh pertama terdapat kata sebanyak-banyaknya. Ucapan terima kasih tidak perlu diikuti kata sebanyakbanyaknya karena memiliki arti yang sama sehingga menimbulkan kemubaziran kalimat. Contoh kedua terdapat kata para setelah kata ibu-ibu. Kata ibu-ibu sudah berarti lebih dari satu sehingga tidak perlu ada kata para.

\section{d. Kontaminasi}

Kontaminasi sering disebut dengan kerancuan kalimat. Kontaminasi merupakan proses atau hasil pengacauan atau penggabungan dua bentuk yang secara tidak sengaja atau tidak lazim dihubungkan (Kridalaksana, 2009 hlm. 108). Kontaminasi menyebabkan kerancuan sehingga kalimat menjadi tidak efektif dan menimbulkan penafsiran yang membingungkan. Penyebab kontaminasi yang sering terjadi adalah seseorang kurang menguasai penggunaan bahasa yang tepat, baik dalam menyusun frasa maupun kalimat menggunakan beberapa imbuhan sekaligus untuk membentuk suatu kata. Selain itu, kontaminasi terjadi dengan tidak sengaja saat seseorang mengucapkan sesuatu kalimat, frasa, maupun kata. Contoh kata yang mengalami kontaminasi, yaitu kata berulang kali dan sering kali. Kata-kata ini 200 terjadi dari kata berulang-ulang dan berkalikali. Kata sering kali kontaminasi dari sering dan banyak kali atau kerap kali atau acap kali.

\section{Surat Dinas}

Silmi, (dalam Kemal, 2013 hlm. 3) menyatakan bahwa surat dinas merupakan surat-surat resmi yang di dalamnya menyangkut berbagai hal tentang kedinasan, misalnya: pengangkatan pegawai, kenaikan pangkat, kenaikan gaji, perpindahan pegawai, keputusan pemberhentian karyawan, dan lain-lain. Surat dinas merupakan surat yang bersifat resmi. Maka dari itu, surat dinas sering diidentikkan dengan surat resmi. Sebenarnya penjenisan surat resmi dan tidak resmi merupakan penjenisan surat berdasarkan sifatnya, sedangkan surat dinas merupakan penjenisan surat berdasarkan pihak yang mengeluarkan dan berdasarkan isi. Perbedaan surat dinas dengan surat resmi dilihat dari bagian-bagian penulisan suratnya, perbedaan yang menonjol dalam surat dinas terdapat kop surat.

Ihsani, dkk., (2018, hlm. 24) menyatakan bahwa dalam surat dinas hendaknya menggunakan bahasa baku dan mengikuti kaidah-kaidah kebahasaan seperti yang telah diatur dalam Pedoman Umum Ejaan Bahasa Indonesia (PUEBI). Media komunikasi menggunakan surat memiliki banyak kelebihan. Menurut Arifin (dalam Purwandari dkk, 2014 hlm. 479) kelebihan surat dibandingkan dengan media komunikasi lisan, yaitu dapat mengurangi kesalahpahaman dalam berkomunikasi karena penulis dapat menyampaikan maksudnya dengan sejelas-jelasnya. Kelebihan yang lainnya menggunakan media surat yaitu ekonois, praktis, dan efektif. Surat dinas adalah surat yang isinya berkaitan dengan kedinasan, baik yang dibuat oleh organisasi maupun instansi. Surat dinas adalah surat yang isinya berkaitan dengan kepentingan tugas dan kegiatan dinas instansi pemerintahan 
(Purwanto, 2006 hlm. 144). Surat dinas tidak hanya dibuat oleh instansi atau lembaga pemerintahan saja, tetapi lembaga swasta pun dapat membuat atau mengeluarkkan surat dinas jika isinya berkaitan dengan urusan kedinasan.

\section{METODE PENELITIAN}

Jenis penelitian yang digunakan dalam penelitian ini adalah penelitian kualitatif dengan menggunakan metode deskriptif. Data dalam penelitian ini yaitu gejala bahasa dalam surat dinas yang dibuat Kantor Desa Pengkol, Kecamatan Nguter, Kabupaten Sukoharjo tahun 2020. Sumber data dalam penelitian ini adalah surat dinas yang dibuat oleh pegawai Kantor Desa Pengkol, Kecamatan Nguter, Kabupaten Sukoharjo tahun 2020. Teknik pengumpulan data dilakukan menggunakan teknik pustaka, simak, dan catat. Teknik pustaka adalah teknik pengumpulan data yang diarahkan mencari data dan informasi melalui dokumen-dokumen yang dibutuhkan. Teknik pustaka berarti peneliti mencari sumber-sumber tertulis untuk dijadikan objek data, sumber tertulis tersebut, yaitu surat dinas pada Kantor Desa Pengkol. Teknik simak dan catat berarti peneliti melakukan penyimakan secara cermat dan teliti terhadap data yang digunakan. Hasil penyimakan dicatat untuk digunakan dalam penyususnan penelitian sesuai dengan maksud dan tujuan yang ingin dicapai. Teknik analisis data yang digunakan dalam penelitian ini adalah teknik kualitatif. Analisis kualitatif secara khusus berasal dari data yang terjaring melalui rekam dan catat, partisipasi, pustaka, serta wawancara (Rohmadi dan Yakub, 2017 hlm. 34). Teknik kualitatif sesuai dengan penelitian ini karena dalam penelitian ini analisisnya tidak menggunakan angka-angka.

\section{PEMBAHASAN}

Penelitian ini akan membahas data yang telah ditemukan pada surat dinas
Kantor Desa Pengkol, Nguter, Sukoharjo. Data akan dikaji sesuai dengan rumusan masalah yang sudah ditetapkan. Berikut adalah bentuk gejala bahasa yang terdapat pada surat dinas kantor Desa Pengkol, Nguter, Sukoharjo.

\section{Tabel 1. Bentuk Gejala}

\begin{tabular}{|c|c|c|}
\hline No. & Data & $\begin{array}{l}\text { Bentuk } \\
\text { Gejala } \\
\text { Bahasa }\end{array}$ \\
\hline 1. & $\begin{array}{l}\text { Rapat koordinasi } \\
\text { percepatan } \\
\text { penanganan pandemi } \\
\text { covid-19. }\end{array}$ & Interferensi \\
\hline 2. & $\begin{array}{lr}\text { Kepada } & \text { warga } \\
\text { terdampak } & \text { virus } \\
\text { covid-19. } & \\
\end{array}$ & Interferensi \\
\hline 3. & Besuk & Hiperkorek \\
\hline 4. & Musola & Hiperkorek \\
\hline 5. & Virus corona & Hiperkorek \\
\hline 6. & Ramadhan & Hiperkorek \\
\hline 7. & Ta'mir & Hiperkorek \\
\hline 8. & Ba'da & Hiperkorek \\
\hline 9. & Sholat & Hiperkorek \\
\hline 10. & Taraweh & Hiperkorek \\
\hline 11. & Baso & Hiperkorek \\
\hline 12. & Devisi & Hiperkorek \\
\hline 13. & Mentaati & Hiperkorek \\
\hline 14. & Himbauan & Hiperkorek \\
\hline 15. & Idul Fitri & Hiperkorek \\
\hline 16. & Idul Adha & Hiperkorek \\
\hline 17. & Bale & Hiperkorek \\
\hline 18. & Korban & Hiperkorek \\
\hline 19. & Dengan & Pleonasme \\
\hline
\end{tabular}




\begin{tabular}{|c|c|c|}
\hline & $\begin{array}{l}\text { mengharap dengan } \\
\text { hormat. }\end{array}$ & \\
\hline 20. & $\begin{array}{l}\text { Dalam rangka } \\
\text { meningkatkan } \\
\text { kewaspadaan dalam } \\
\text { menyikapi tentang } \\
\text { virus corona. }\end{array}$ & Pleonasme \\
\hline 21. & $\begin{array}{lr}\text { Rapat } & \text { koordinasi } \\
\text { persiapan } & \text { ibadah } \\
\text { bulan } & \text { suci } \\
\text { Ramadhan } & \text { tahun } \\
\text { 1441 H. } & \end{array}$ & Pleonasme \\
\hline 22. & $\begin{array}{l}\text { Rapat koordinasi } \\
\text { bulan Mei } 2020 .\end{array}$ & Pleonasme \\
\hline 23. & $\begin{array}{l}\text { Persiapan menjelang } \\
\text { Hari Raya Idul Fitri } \\
1441 \mathrm{H} \text {. }\end{array}$ & Pleonasme \\
\hline 24 & $\begin{array}{l}\text { Mengikuti dan } \\
\text { membantu kegiatan } \\
\text { Kecamatan Nguter. }\end{array}$ & Pleonasme \\
\hline 25. & $\begin{array}{l}\text { Rapat koordinasi } \\
\text { menjelang Hari Raya } \\
\text { Idul Adha } 1441 \mathrm{H} \text {. }\end{array}$ & Pleonasme \\
\hline 26. & \begin{tabular}{lr} 
Tetap & mentaati \\
himbauan & dari \\
pemerintah & dengan \\
mengikuti & protokol \\
kesehatan & semua \\
harus pakai & masker \\
\multicolumn{2}{c}{ dan jaga jarak. }
\end{tabular} & Pleonasme \\
\hline 27. & $\begin{array}{lr}\text { Demikian } & \text { untuk } \\
\text { menjadikan } & \text { maklum } \\
\text { dan } & \text { atas } \\
\text { kehadirannya } & \text { kami } \\
\text { ucapkan } & \text { terima } \\
\text { kasih. } & \\
\end{array}$ & Kontaminasi \\
\hline 28. & $\begin{array}{lr}\begin{array}{l}\text { Dengan } \\
\text { kehadiran }\end{array} & \text { hormat } \\
\text { dalam } & \text { Bapak } \\
\text { penyaluran } & \text { Bangka } \\
\text { Langsung } & \text { Tunai } \\
(\text { BLT) dari dana desa } \\
\text { untuk } & \text { tahun } \\
\text { anggaran } & 2020 \text { pada } \\
\text { hari: }\end{array}$ & Kontaminasi \\
\hline 29. & $\begin{array}{lr}\text { Apabila } & \text { sudah } \\
\text { warga } & \text { yang } \\
\text { mendaftar } & \text { ikut } \\
\end{array}$ & Kontaminasi \\
\hline
\end{tabular}

\begin{tabular}{|l|lr|}
\hline korban & di & mohon \\
takmir & masjid & dan \\
musholla & di & harap \\
membawa & data & \\
jumlah & korban \\
ataupun & kelompok & \\
kurban lembu. & \\
\hline
\end{tabular}

\subsection{Bentuk Gejala Interferensi}

Interferensi adalah salah satu bentuk gejala bahasa yang sering digunakan oleh penutur, terutama yang menguasai lebih dari satu bahasa. Interferensi merupakan salah satu peristiwa masuknya unsur bahasa asing atau bahasa daerah ke dalam bahasa yang sedang digunakan. Di bawah ini akan dijelaskan data yang menimbulkan bentuk gejala interferensi.
(1) Rapat koordinasi percepatan penanganan pandemi covid-19.
(2) Kepada warga terdampak virus covid-19.

Data (1) dan (2) merupakan bentuk gejala interferensi, yaitu masuknya bahasa asing dalam bahasa yang digunakan. Kedua data tersebut memiliki kesamaan terdapat bahasa asing covid-19, sedangkan bahasa yang digunakan adalah bahasa Indonesia. Covid-19 menurut website WHO adalah singkatan dari "Corona Virus Disaese", sedangkan 19 adalah tahun pertama virus tersebut ditemukan. Bahasa Covid-19 dalam bahasa Indonesia disebut koronavirus. Kata tersebut juga sudah ada dalam Kamus Besar Bahasa Indonesia Daring Edisi V. Jadi agar tidak menimbulkan gejala interferensi makan kata Covid-19 diubah dengan kata koronavirus.

\subsection{Bentuk Gejala Hiperkorek}

Gejala hiperkorek merupakan pembetulan kata yang sudah benar sehingga menjadi salah. Gejala tersebut berhubungan dengan penambahan, pengurangan ataupun pengubahan fonem 
pada kata yang digunakan. Gejala hiperkorek berkaitan dengan bahasa baku. Berikut ini akan dijelaskan data yang menimbulkan bentuk gejala hiperkorek.

(3) Dengan ini mengharap dengan hormat atas kehadiran $\mathrm{Bp} / \mathrm{Ibu}$ besuk pada.

Data (3) termasuk hiperkorek karena terdapat kata besuk, kata tersebut menggunakan fonem /u/ sedangkan yang betul menggunakan fonem /o/. sehingga menjadi kata besok yang berarti hari sesudah hari ini dalam Kamus Besar Bahasa Indonesia. Kesalahan penulisan fonem tersebut, biasanya karena pengucapan kata penutur menggunakan fonem $/ \mathrm{u} /$ bukan fonem $/ \mathrm{o} /$. Biassanya hal itu terjadi dikarenakan kebiasaan dari masyarakat yang biasa menyebutkan kata besok dengan penyebutan besuk.

(4) Takmir Masjid dan Musola Sedesa Pengkol

Data (4) termasuk gejala bahasa hiperkorek. Seseorang sudah terbiasa menuturkan kata musola menggunakan fonem /o/ padahal yang benar menggunakan fonem /a/. Kata musala berasal dari serapan bahasa arab: Sُصَتلَى Seseorang yang membacanya musola, maka dari itu orang menganggap bahwa yang benar itu kata musola bukan musala. Musala adalah tempat untuk beribadah yang bentuknya lebih kecil dari pada masjid. Dalam Kamus Besar Bahasa Indonesia Edisi Kelimat musala adalah tempat salat, ;anggar, surau. Di masyarakat memang lebih terkenal dengan kata musola. Banyak masyarakat awam belum mengetahui bahwa yang benar adalah musala.

(5) Rapat Koordinasi Percepatan Penanganan Pandemi covid-19
(Virus Corona) dengan Tokoh Masyarakat Desa Pengkol.

Data (5) terdapat kata virus corona, dilihat secara umum kata tersebut merupakan penulisan yang benar, karena pertama kali virus itu muncul orang-orang menyebutnya dengan kata virus corona sehingga menjadi istilah yang populer. Virus corona dalam Kamus Besar Bahasa Indonesia Edisi Kelima adalah kata tidak baku dari koronavirus. Koronavirus berasal dari bahasa latin corona yang artinya mahkota, yang mengacu pada tampilan partikel virus menyerupai mahkota pada pinggirannya.

(6) Rapat Koordinasi Persiapan Ibadah Bulan Suci Ramadhan Tahun 1441 $\mathrm{H}$.

Data (6) terdapat kata ramadhan yang merupakan kata tidak baku dari kata 'ramadan'. Kata tersebut termasuk bentuk gejala hiperkorek, karena terdapat penambahan fonem $/ \mathrm{h} /$ pada kata ramadan. Penambahan fonem $/ \mathrm{h} / \mathrm{pada}$ kata tersebut dianggap benar pada kebanyakan orang, padahal adanya fonem $/ \mathrm{h} /$ tersebut menjadi salah. Ramadan berasal dari akar kata bahasa Arab ramida atau ar-ramad, yang berari panas yang menghanguskan atau kekeringan.

(7) Ta'mir Masjid dan Mushola se Desa Pengkol

Data (7) terdapat kata ta'mir sehingga menyebabkan terjadinya gejala bahasa hiperkorek. Kata ta'mir dalam Kamus Besa Bahasa Indonesia Edisi Kelima yang benar adalah "takmir". Kata ta'mir di anggap benar oleh masyarakat karena merupakan serapan dari bahasa arab yang ditulis ta'mir terdapat "ain" yang berarti memakmurkan. Sedangkan dalam Kamus Besar Bahasa Indonesia takmir 
terdapat dua arti, yang pertama upaya memakmurkan dan kedua, berarti pengurus masjid. Masyarakat mengibaratkan penulisan tersebut seperti penulisan dalam bahasa Arab.

(8) Ba'da Sholat Taraweh.

Data (8) terapat kata ba'da sehingga menyebabkan terjadinya hiperkorek. Ba'da dalm Kamus Besar Bahasa Indonesia Edisi Kelima ditulis "bakda". Penulisan tersebut salah tetapi membacanya sama. Menurut masyarakat awam tulisan tersebut sudah benar, namun penulisan itu sebenarnya salah. Bakda berarti sesudah. Biasanya seseorang menggunakan kata bakda yang berkaitan dengan salat, seperti bakda subuh, bakdah magrub, bakda isya, dan sebagainya. Masyarakat mengibaratkan penulisan tersebut seperti penulisan dalam bahasa Arab.

(9) Ba'da Sholat Taraweh.

Data (9) terdapat kata $\begin{array}{r}\text { sholat } \\ \text { gejala }\end{array}$
sehingga Kenyebabkan
hiperkorek. Kata sholat pada Kamus
Besar Bahasa Indonesia Edisi Kelima
tidak menggunakan fonem /h/ dan fonem
/o/ diganti dengan fonem /a/, sehingga
penulisan yang benar adalah "salat".
Pada kehidupan sehari-hari masyarakat
sering mengucapkan kata sholat
disbanding kata salat. Kata salat
merupakan kata serapan bahasa Arab.
Salat mempunyai arti ibadah yang wajib
dilakukan oleh setiap muslim. Salat juga
merupan rukun islam kedua. Kata salat
bagi masyarakat awam memang jarang
digunakan. Karena dari dulu masyarakat
lebih terbiasa menyebutnya dengan kata
sholat.

(10) Ba'da Sholat Taraweh.

Data (10) terdapat kata taraweh yang merupakan kata tidak baku dari "tarawih". Pada kata tersebut fonem /e/ diganti dnegan fonem (i). sebagian orang menganggap jika fonem di ganti /i/ pengucapannya akan terdengar aneh. Tarawih adalah salat sunah pada malam hari dilakukan pada waktu sesudah isya maupun sebelum subuh selama bulan ramdan.

(11) Halaman Warung Baso Kirana Desa Pengkol Kecamatan Nguter Kabupaten Sukoharjo.

Data (11) terdapat kata baso yang merupakan bentuk tidak baku dari kata "bakso". Tidak adanya fonem /k/ menyebabkan terjadinya bentuk gejala bahasa hiperkorek. Masyarakat umum sudah tidak asing lagi dengan makanan yang satu ini, mereka sering mengucapkan kata baso, karena mereka menganggap lebih mudah dan simple untuk diucapkan, terutama dalam mengajarkan anak berbicara. Selain itu, orang yang sudah lanjut usia juga lebih suka mengucapkan baso dibandingkan mengucapkan bakso. Bakso dalam Kamus Besar Bahasa Indonesia Edisi Kelima mempunyai arti makanan yang terbuat dari daging, ikan maupun udang yang dicincang dan dicampur dengan tepung, biasanya dibentuk bulat-bulat. Masyarakat Jawa memang lebih suka mengucapkan kata-kata yang singkat. Hal itu berdampak dalam pembuatan surat dinas. Surat dinas yang seharusnya dibuat menggunakan bahasa yang baku tetapi malah tidak menggunakan bahasa baku.

(12) Kepala Sub. Devisi III/I Perum.

Data (12) terdapat kata devisi sehingga menyebabkan adanya bentuk gejala hiperkorek. Kata devisi hiperkorek, karena menggunakan fonem le/ yang seharusnya diganti dengan fonem /i/. Sehingga, menjadi kata "divisi". Perubahan fonem /i/ menjadi fonem /e/, bisa dilator belakangi dari asal daerah penutur. Divisi dalam Kamus 
Besar Bahasa Indonesia Edisi Kelima mempunyai beberapa arti salah satunya yang berkaitan dengan kalimat tersebut memiliki arti bagian dari suatu perusahaan besar.

(13) Tetap Mentaati himbauan dari Pemerintah dengan mengikuti Protokol Kesehatan semua harus pakai masker, jaga jarak (sosial distancing) dan cuci tangan ditempat yang telah di sediakan.

Data (13) terdapat kata mentaati sehingga terjadi bentuk gejala bahasa hiperkorek. Kata yang benar, yaitu menaati tanpa ada fonem /n/. menaati adalah kata turunan dari kata 'taat'. Kata menaati mendapat imbuhan me- dan $-\mathrm{i}$. me- + taat $+-\mathrm{i}=$ menaati, bukan mentaati, karena /t/ harus diluluhkan menjadi /n/. Kata mentaati merupakan kata yang sering digunakan dalam kehidupan sehari-hari. Banyak masyarakat yang belum mengetahui bahwa yang betul itu menaati.

(14) Tetap Mentaati himbauan dari Pemerintah dengan mengikuti Protokol Kesehatan semua harus pakai masker, jaga jarak (sosial distancing) dan cuci tangan ditempat yang telah di sediakan.

Data (14) terdapat kata himbauan yang merupakan bentuk kata tidak baku dari kata "imbauan". Kata himbauan termasuk bentuk gejala hiperkorek, karena penulisannya menambah fonem $/ \mathrm{h} /$. kata imbauan merupakan kata turunan dari kata 'imbau', yang mendapat sufiks -an. Banyak masayarakat umum yang masih menggunakan kata himbau daripaada kata imbau. Imbauan dalam Kamus Besar Bahasa Indonesia Edisi Kelima mempunyai arti panggilan, permintaan, dan ajakan. Kata imbauan memang lebih mudah diucapkan tetapi masyarakat lebih suka menggunakan kata himbauan.
(15) Rapat Koordinasi Percepatan Penanganan Pandemi Virus Corona/Covid-19 dan Persiapan Menjelang Hari Raya Idul Fitri 1441 $\mathrm{H}$.

Data (15) terdapat kata Idul Fitri, seharusnya kata tersebut digabung sehingga menjadi "idulfitri". Banyak masyarakat umum yang belum mengerti mengenai penulisan kata tersebut. Terbukti, banyak spanduk-spanduk pada saat bulan Ramadan yang masih salah penulisannya. Terkadang masyarakat malah berpikir jika penulisannya digabung itu salah.

(16) Rapat Koordinasi menjelang Hari Raya Idul Adha 1441 H/2020 M.

Data (16) terdapat kata idul adha, seperti data (15) seharusnya penulisan kata tersebut di gabung. Penulisan yang benar, yaitu "iduladha". Masyarakat juga menganggap penulisan yang benar itu dipisah dan hingga sekarang masih banyak penulisan yang dipisah karena sudah turun temurun. Bahkan di kalangan pemerintahan juga menganggap penulisan yang sesuai itu di pisah.

(17) Pendopo Bale Desa Pengkol

Data (17) terdapat kata bale merupakan kata tidak baku dari kata "balai". Kata bale hiperkorek, karena fonem /a/ dan /i/ diganti dengan fonem /e/. Gejala tersebut muncul biasanya dipengaruhi oleh daerah asal penutur. Masyarakat Jawa sering menuturkan kata bale daripada kata balai, sehingga menjadi kebiasaan. Menurut mereka pengucapan bale lebih mudah, padahal itu menyebabkan gejala bahasa. Biasanya hal tersebut dilakukan oleh orang Jawa.

(18) Apabila sudah ada warga yang mendaftar ikut korban dimohon 
takmir masjid dan musholla diharap membawa data jumlah korban ataupun kelompok kurban lembu.

Data (18) terdapat kata korban sehingga menimbulkan hiperkorek. Korban sebenarnya kata baku yang terdapat dalam Kamus Besar Bahasa Indonesia, namun dalam konteks kalimat tersebut kata korban tidak sesuai. Adanya kesalahan pengucapan fonem /u/ menjadi fonem /o/ yang dilakukan oleh masyarakat Jawa menimbulkan terjadinya hiperkorek. Seharusnya kata korban diganti dengan kata "kurban". Hal tersebut terjadi karena kebiasaan orang Jawa yang sering menyebutkan kata kurban menjadi korban. Padahal korban memiliki arti yang sangat berbeda dengan kurban.

\subsection{Bentuk Gejala Pleonasme}

Gejala Pleonasme atau yang sering disebut kemubaziran. Pleonasme merupakan penggunaan kata yang berlebihan, sehingga menyebabkan kalimat tidak efektif dan terjadi pemborosan makna kata. Masyarakat sering menggunakan gaya bahasa tulis maupun lisan yang berlebihan, padahal kata tersebut memiliki makna yang sama. Tidak dipungkiri dalam penulisan surat dinas juga terdapat kata mubazir. Berikut akan dijelaskan data yang menimbulkan bentuk gejala pleonasme atau kata mubazir.

(19) Dengan ini mengharap dengan hormat.

Data (19) terdapat bentuk gejala pleonasme, yaitu pengulangan kata dengan. Agar tidak terjadi gejala pleonasme maka penulisannya sebagai berikut "Mengharap dengan hormat." Kata dengan pada awal kalimat dihilangkan.

(20) Dalam rangka meningkatkan kewaspadaan dalam menyikapi tentang virus corona.
Data (20) terdapat bentuk gejala pleonasme, yaitu kemubaziran kata. seharusnya pada kata menyikapi dan tentang dipilih salah satunya saja.

(21) Rapat koordinasi persiapan ibadah bulan suci Ramadhan tahun 1441 $\mathrm{H}$.

Data (20) terdapat bentuk gejala pleonasme, yaitu pada kalimat bulan suci Ramadan. Alasan mengapa terjadi pleonasme, karena terdapat kemubaziran kalimat. Bulan suci dalam Kamus Besar Bahasa Indonesia Edisi Kelima mempunyai arti bulan Ramadan. Kalimat bulan suci Ramadan berarti "bulan Ramadan Ramadan", maka dari itu kalimat tersebut diganti menjadi bulan Ramadan. Selain itu, kata tahun seharusnya dihilangkan. Tanpa ada tulisan tahun angka tersebut sudah mewakilinya.

(22) Rapat koordinasi bulan Mei 2020.

Data (22) terdapat gejala pleonasme pada kata bulan Mei. Mei dalam Kamus Beasr Bahasa Indonesia mempunyai atri bulan ke-5 tarikh Masehi. Sehingga, jika penulisannya seperti di atas maka kalimat tersebut mempunyai makna "bulan bulan Mei". Tanpa disertakan kata bulan, semua orang sudah paham bahwa Mei adalah salah satu nama bulan dalam Masehi.

(23) Persiapan menjelang Hari Raya Idul Fitri $1441 \mathrm{H}$.

Data (23) terdapat gejala pleonasme pada kalimat hari raya Idul Fitri. Idulfitri dalam Kamus Besar Bahasa Indonesiia edisi kelima mempunyai arti hari raya umat Islam yang jatuh pada tanggal 1 syawal setelah selesai menjalankan ibadah puasa selama bulan Ramadan. Idulfitri memililki arti hari raya, jika kedua kata tersebut ditulis bersamaan terjadi kemubaziran kata. 
Maka dari itu, penulisan kalimat di atas agar efektif berubah menjadi "Persiapan menjelang idulfitri $1441 \mathrm{H}$ ".

(24) Mengikuti dan membantu kegiatan Kecamatan Nguter.

Data (24) terdapat gejala pleonasme pada kalimat mengikuti dan membantu. Mengikuti mempunyai arti mengiring; menyertai, sedangkan membantu mempunyai arti memberi sokongan (tenaga atau yang lainnya) dan menolong. Jika sudah membantu, maka secara tidak langsung kita sudah mengikuti kegiatan tersebut. Kalimat yang efektif dalam penulisan di atas, yaitu membantu kegiatan Kecamatan Nguter.

(25) Rapat koordinasi menjelang Hari Raya Idul Adha $1441 \mathrm{H}$.

Data (24) terdapat gejala pleonasme pada kalimat Hari Raya Idul Adha. Iduladha dalam Kamus Besar Bahasa Indonesiia Edisi Kelima mempunyai arti hari raya haji yang jatuh pada tanggal 10-13 Zulhijah yang disertai dengan penyembelihan hewan kurban bagi yang mampu. Kata iduladha sudah mewakili kata hari raya. Jadi, penulisan kalimat di atas agar menjadi kalimat efektif adalah "Rapat koordinasi menjelang iduladha $1441 \mathrm{H}$ ".

(26) Tetap mentaati himbauan dari pemerintah dengan mengikuti protokol kesehatan semua harus pakai masker dan jaga jarak.

Data (26) merupakan contoh kalimat yang tidak efektif. Sebaiknya kalimat di atas ditulis "Tetap menaati protokol kesehatan". Menaati protokol kesehatan merupakan imbauan dari pemerintah sehingga tidak perlu ditulis. "semua harus pakai masker dan jaga jarak" juga tidak perlu ditulis, karena kalimat tersebut sudah termasuk jenis protokol kesehatan.

(27) Demikian untuk menjadikan maklum dan atas kehadirannya kami ucapkan terima kasih.

Data (27) terjadi bentuk gejala pleonasme, karena terdapat kalimat untuk menjadikan maklum. Kalimat tersebut berisi sebuah harapan, yaitu harapan agar penerima surat merasa maklum dengan apa yang disampaikan dalam pokok surat. Sebenarnya permohonan untuk merasa maklum ini tidak perlu ditulis karena tanpa diminta untuk maklum pun penerima surat pasti dapat mengetahui isinya.

(28) Dengan hormat kehadiran Bapak dalam rangka penyaluran Bantuan Langsung Tunai (BLT) dari dana desa untuk tahun anggaran 2020 pada hari:

Data Kalimat pada data (28) memiliki susunan unsur bahasa yang kurang tepat, sehingga kalimat menjadi rancu. Alinea pembuka yang dibuat untuk menyatakan tujuan yang akan dilaksanakan, yaitu sebagai berikut. "Dalam rangka penyaluran Bantuan Langsung Tunai (BLT) dari dana desa tahun anggaran 2020 kami mohon kehadiran Bapak pada hari:". Kalimat tersebut lebih mudah dipahami dibandingkan dengan kalimat di atas.

(29) Apabila sudah ada warga yang mendaftar ikut korban di mohon takmir masjid dan musholla di harap membawa data jumlah korban ataupun kelompok kurban lembu.

Data (29) terjadi bentuk gejala pleonasme karena kalimat bertele-tela dan terjadi pengulangan kata yang maknanya sama. Sebaiknya penulisan kalimat di atas adalah sebagai berikut: "Warga yang sudah mendaftar kurban mohon takmir masjid dan musala membawa jumlah datanya". Kalimat 
pada surat dinas harus ditulis secara efektif berbeda dengan surat pribadi.

\subsection{Bentuk Gejala Kontaminasi}

Kontaminasi adalah salah satu bentuk gejala bahasa yang membuat kerancuan suatu kalimat. Kontaminasi biasanya terjadi penambahan kata yang memiliki makna berbeda, sehingga kata tersebut susah untuk dipahami dan menjadi rancu. Berbeda dengan pleonasme, pleonasme menambahkan kata yang memiliki makna sama sehingga kalimat menjadi bertele-tele. Kontaminasi terjadi, karena susunan unsur bahasa yang kurang tepat. Berikut ini akan dijelaskan bentuk gejala bahasa yang terdapat pada surat dinas di kantor Desa Pengkol, Nguter, Sukoharjo.

(30) Dengan hormat kehadiran Bapak dalam rangka penyaluran Bantuan Langsung Tunai (BLT) dari dana desa untuk tahun anggaran 2020 pada hari:

Kalimat pada data (28) memiliki susunan unsur bahasa yang kurang tepat, sehingga kalimat menjadi rancu. Alinea pembuka yang dibuat untuk menyatakan tujuan yang akan dilaksanakan, yaitu sebagai berikut. "Dalam rangka penyaluran Bantuan Langsung Tunai (BLT) dari dana desa tahun anggaran 2020 kami mohon kehadiran Bapak pada hari:". Kalimat tersebut lebih mudah dipahami dibandingkan dengan kalimat di atas.

(31) Dalam rangka meningkatkan kewaspadaan dalam menyikapi tentang virus corona

Kalimat pada data (31) memiliki susunan bahasa yang rancu, sehingga menimbulkan pembaca susah untuk memahaminya dan kalimat terlalu bertele-tele. Kata dalam dan kata tentang seharusnya dihilangkan saja, sehingga penulisan menjadi "Dalam rangka meningkatkan kewaspadaan menyikapi virus korona." Penghilangan dua kata tersebut tidak merubah makna dalam kalimat di atas dan kalimat menjadi lebih efektif.

\section{PENUTUP}

Berdasarkan hasil analisis dari penelitian ini, maka dapat disimpulkan bahwa terdapat 4 bentuk gejala bahasa yang terdapat dalam surat dinas di kantor Desa Pengkol, Nguter, Sukoharjo. Bentuk gejala bahasa tersebut, yaitu gejala interferensi, gejala hiperkorek, pleonasme, dan kontaminasi. Dari keempat bentuk gejala tersebut, gejala bahasa yang sering mucul adalah bentuk gejala bahasa hiperkorek, sedangkan yang paling sedikit bentuk gejala bahasa interferensi. Hal ini menunjukkan bahwa keterampilan menulis pegawai pemerintahan masih rendah hal tersebut terbukti dari surat-suart yang dibuat masih banyak terjadi gejala bahasa. Perlu adanya langkah strategis dari pemerintah dalam memberikan pelatihan-pelatihan kepada pegawai pemerintahan.

\section{DAFTAR PUSTAKA}

Adib, Holy. (2019). Pendekar Bahasa. Bantul: BASABASI.

Ali, Adlan dan Tanzili. (2006). Pedoman Lengkap Menulis Surat. Tangerang: Kawan Pustaka:

Anggara, S.N., Prabawa, Prabawa, A.H., \& Rahmawati. R.E. (2020). Tindak Tutur Asertif pada Rubrik "AH TENANE" Surat Kabar Solopos. Jurnal Totobuang, 8(2), 341-353.

Dewi, N. K., \& Nuraeni, L. (2019). Gejala Morfofonemik Bahasa Sunda pada Tuturan Anak Usia Dini di Wilayah Kuningan. EDUCATOR, 5(1), 45-52.

Gita, Neinilam. (2018). 45 Kesalahan Penulis Wattpad. Tangerang: GD Press.

Henilia, H. (2021). Beberapa Gejala Bahasa dalam Bahasa Indonesia. Juripol 
(Jurnal Institusi Politeknik Ganesha Medan), 4(1), 18-23.

Henilia. (2021). Beberapa Gejala Bahasa dalam Bahasa Indonesia. Jurnal Insitusi Politeknik Ganesha Medan, 4(1): 18-23.

Hesti, H., Mustofa, R., \& Wati, I. (2021). Gejala Bahasa dalam Karangan Argumentasi Siswa Kelas X SMAN 9 Bandar Lampung. Pena Literasi, 4(1), 20-28.

Ihsani, B. Y., Untari, T., \& Darmutika, L. A. (2018). Pelatihan Penulisan Surat Dinas pada Perangkat Kantor Desa Jatisela Kecamatan Gunung Sari Lombok Barat. JCES (Journal of Character Education Society), 1(1), 23-29.

Kemal, I. (2013). Kemampuan Menulis Surat Dinas. Jurnal Metamorfosa, 1(1), $1-10$.

Kridalaksana, H. (1993). Kamus Linguistik. Jakarta: Gramedia.

Kridalaksana, Harimurti. (2009). Kamus Linguistik Edisi Keempat. Jakarta: PT Gramedia.

Markhmah dan Atiqa Sabardila. 2014. Analisis Kesalahan dan Karakteristik Bentuk Pasif. Surakarta: Muhammadiyah University Press.

Muslich, Masnur. (2013). Tata Bentuk Bahasa Indonesia, Kajian ke Arah Tata Bahasa Deskriptif. Jakarta: Bumi Aksara.

Nasucha, Yakub. (2019). Metode Pembelajaran dalam Pendekatan PILABAH. Surakarta: Yuma Pustaka.
Ngalim, Abdul. (2015). Sosiolinguistik: Suatu Kajian Fungsional. Sukoharjo: Jasmine.

Purwandari, Heni Setya, Budhi Setiawan, dan Kundharu Saddhono. 2014. "Analisis Kesalahan Berbahasa Indonesia pada Surat Dinas Kantor Desa Jladri”. Jurnal Penelitian Bahasa, Sastra Indonesia dan Pengajarannya. 1(3): 478-498.

Pratiwi, Ika Agustina, dkk. (2013). Gejala Bahasa Siswa Kelas X dan Implikasinya terhadap Pembelajaran Bahasa Indonesia. Jurnal Kata, 1(1): 1-10.

Rohmadi, Muhammad dan Yakub Nasucha. (2017). Dasar-Dasar Penelitian: Bahasa, Sastra, dan Pengajarannya. Surakarta: Pustaka Briliant.

Saryono, Djoko dan Soedjito. (2020). KOSAKATA. Jakarta Timur: Bumi Akasara.

Sukoyo, Joko. (2011). Interferensi Bahasa Indonesia dalam Acara Berita Berbahasa Jawa "Kunthane Dhewe" di TV Borobudur Semarang". Lingual Jurnal Bahasa dan Sastra, 7(2):95103.

Waljinah, S., Prayitno, H. J., Purnomo, E., Rufiah, A., \& Kustanti, E. W. (2019). Tindak Tutur Direktif Wacana Berita Online: Kajian Media Pembelajaran Berbasis Teknologi Digital. SeBaSa, 2(2), 118-129. 
